\title{
PHARMACY
}

\section{THE RESULTS OF CLUSTER ANALYSIS OF UKRAINIAN REGIONS PROVISION BY PHARMACIES}

\author{
Candidate of pharmaceutical sciences, Associate professor Hala L. O. \\ Ukraine, Kyiv, National Medical University named after O. O. Bogomolets, \\ Chair of Management and Economy of Pharmacy
}

DOI: https://doi.org/10.31435/rsglobal_ws/31082019/6625

\begin{abstract}
ARTICLE INFO
Received: 22 June 2019

Accepted: 16 August 2019

Published: 31 August 2019

\section{KEYWORDS}

cluster analysis, pharmacy, pharmaceutical supply system, pharmaceutical care, pharmaceutical service.

ABSTRACT

The results of regions cluster analysis of the pharmacies in their total quantity in Ukraine from 2012 to 2019 have been presented. According to the objectives, five clusters have been built with different dynamics of years. Most regions were represented in the fourth cluster which consisted of 9 ones $(37.5 \%$ of their total number). This cluster was characterized by a growing trend in indicators from 2012 to 2019. The most problematic from the socioeconomic point of view were the first (Lugansk) and third (Donetsk) regions, which, unlike all others, showed a sharp decrease of indicators in 2016 in comparison with other Ukrainian regions. The results obtained can be used for effective implementation of state regulation mechanisms in the retail pharmaceutical market of Ukraine.
\end{abstract}

Citation: Hala L. O. (2019) The Results of Cluster Analysis of Ukrainian Regions Provision by Pharmacies. World Science. 8(48), Vol.1. doi: 10.31435/rsglobal_ws/31082019/6625

Copyright: (C) 2019 Hala L. O. This is an open-access article distributed under the terms of the Creative Commons Attribution License (CC BY). The use, distribution or reproduction in other forums is permitted, provided the original author(s) or licensor are credited and that the original publication in this journal is cited, in accordance with accepted academic practice. No use, distribution or reproduction is permitted which does not comply with these terms.

Introduction. The world pharmacies are gradually increasing their impact on the population by providing accessible medical and pharmaceutical care $[1,3]$. In most countries which are developing as to implement efficient relationship models in pharmaceutical market (PM), the key role belongs to pharmacies, in particular. According to experts in the poorest countries pharmacies are the only medical care institution which is geographically available for socially vulnerable groups of population $[3,5,6]$. At the beginning of 2015 in response to social expectations of system changes the President of Ukraine signed the act on «The Development Strategy «Ukraine-2020» where 62 reforms implementation is declared. Among those reforms the changes in the system of the national health care and pharmaceutical supply of population took priority [7]. In 2018 the first draft №8591 on «Amendments «About medical products» to Law of Ukraine in order to provide economic competitiveness and protect patients' rights at retail trade of medical products» was submitted to Verkhovna Rada. The document establishes standards which drastically change laws and regulations and economic management mechanisms to provide pharmaceutical service at retail trade, in particular, in PM [11]. Ukraine is known to be among the countries where the government does not interfere with order of pharmaceutical chain placement by geographical pressure (distance between pharmacies) and demographic one (customers number who are given services by one pharmacy) $[2,10]$. Firstly, the law requires introducing geographical parameter into the state regulation of pharmaceutical chain a minimal distance (500 meters) between two pharmacies. The significant regulatory mechanism is limiting the pharmacy number within the pharmaceutical chain depending on form of ownership and assortment of medical products for sale. Physical persons as subjects of entrepreneurial activity as well as paramedic and obstetric units in villages can have 1 pharmacy at maximum and legal entity - maximum quantity of 4 in the pharmaceutical chain. The pharmacies which are engaged into making medicine by doctor's prescription and also selling narcotic and psychotropic drugs and precursors 
are allowed to have 8 pharmacies in the chain at maximum. Another innovation to be implemented is a regulatory requirement for the pharmacy's owner to have a pharmaceutical qualification not lower than the second (master) level of education in «Pharmacy»; the certificate of pharmacist issued by the postgraduate educational establishment which can confirm the corresponding qualification level [11]. Having studied the professional literature we can state that the mentioned above innovations have been introduced to practice in most countries of the European Union [2,4,10]. Thus, for example the list of similar in content and regulatory standards of retail operations in PM was adopted in the Republic of Poland in 2017 [2,4]. The experts are said to note the negative consequences of introducing the state regulatory mechanisms of placing pharmaceutical network in Poland which foremost had an impact on pharmaceutical supply in villages. Taking into account everything said above it is topical to analyze how different regions of Ukraine are supplied by pharmacies in dynamics for the last few years. The research done is of high socioeconomic significance because of the meaningful difference in economic development parameters of different administrative territorial units of the country considering the geographical characteristics to form demographical pressure on pharmacies in the regions of Ukraine.

The purpose of the research is to analyze clusters as to how they provide pharmaceutical service in different regions of Ukraine in dynamics for several years and to determine the regions which require special attention in case new state regulations are introduced at retail trade in PM.

The materials and methodology of the research. The research objective was the data of the analytical system «PharmXplorer»/《Pharmstandard» of the company «Proxima Research». To form the required statistic data base was used the uniform methodology approach that is why to analyze indicators in dynamics of the last several years (2012-2019) is scientifically reasonable. Considering the purpose and content of the designed objectives the cluster analysis was chosen as the main research instrument. The purpose of the cluster analysis is known to divide the specified aggregate of objects into subsets (clusters) so that every cluster consists of similar objects and the objects of different clusters differ significantly [8,9]. Clusterization by k-averaging method is a method to categorize a set of objects into comparatively homogeneous groups and every cluster is outlined by a uniform average vector. The method is based on the sum of squared distances between every observation and its center cluster i.e. the function:

$$
\sum_{i=1}^{N} d\left(x_{i}, m_{j}\left(x_{i}\right)\right)^{2}[8,9],
$$

where $d$-metric; $x_{i}-i$-th data object; $m_{j}\left(x_{i}\right)$-the cluster center which assigned to the element $x_{i}$ at the $j$-th iteration; $N$ - quantity of objects.

Euclidean distance is used as metric:

$$
d_{i j}=\sqrt{\sum_{k=1}^{p}\left(x_{i k}-x_{j k}\right)^{2}}[8,9],
$$

where $x_{i k}, x_{j k}-k$-th coordinate of the $i$-th and $j$-th objects correspondingly.

The cluster center is a conventional object the coordinates of which are calculated as average value of the object characteristics that relate to this cluster, i.e. $k$-th coordinate of the cluster center $n$ is determined by the following formula:

$$
x_{k}^{(n)}=\frac{1}{N_{n}} \sum_{l=1}^{N_{n}} x_{l k}[8,9],
$$

where $x_{k}^{(n)}-k$-th coordinate of the center of $n$-th cluster, $x_{l k}-k$-th coordinate of the $l$-th object in the cluster; $N_{n}$ - quantity of objects in the $n$-th cluster.

According to the designed objectives of the research every administrative territorial unit (oblasts and Kyiv city $)$ of the country corresponds to the calculated vector $\vec{a}=\left(a_{1}, a_{2}, a_{3}, a_{4}, a_{5}, a_{6}, a_{7}\right)$ which describes dynamics of value change of the «Number of pharmaceutical establishments (Sales Points)» indicator. The latter indicator was normalized to the total number of pharmacies all over Ukraine which in the experiment were called «Sales Points» (SP). The initial data to analyze is shown in table 1. 
Table 1. Initial data for cluster analysis

\begin{tabular}{|l|c|c|c|c|c|c|c|}
\hline \multirow{2}{*}{$\begin{array}{c}\text { Region (oblasts and Kyiv } \\
\text { city) }\end{array}$} & \multicolumn{6}{|l}{ Specific weight (\%) of SP of the total pharmacy number in Ukraine during } \\
\cline { 2 - 8 } & 2012 & 2014 & 2015 & 2016 & 2017 & 2018 & 2019 \\
\hline Dnipropetrovsk region & 7,52 & 7,43 & 7,6 & 8,52 & 7,85 & 7,66 & 7,58 \\
\hline Donetsk region & 8,35 & 8,43 & 7,64 & 4,2 & 4,38 & 4,45 & 4,93 \\
\hline Luhansk region & 5,28 & 5,44 & 4,6 & 1,93 & 2,88 & 1,69 & 2,08 \\
\hline Kharkiv region & 5,93 & 6,05 & 5,98 & 6,64 & 6,56 & 6,66 & 6,47 \\
\hline Volyn region & 2,07 & 1,97 & 2,05 & 2,33 & 2,32 & 2,39 & 2,35 \\
\hline Zakarpattia region & 3,15 & 3,1 & 3,21 & 3,59 & 3,67 & 3,73 & 3,54 \\
\hline Ivano-Frankivsk region & 3,37 & 3,29 & 3,45 & 3,92 & 3,9 & 3,85 & 3,89 \\
\hline Lviv region & 5,39 & 5,36 & 5,46 & 6,17 & 5,97 & 6,08 & 5,86 \\
\hline Rivne region & 2,14 & 2,26 & 2,44 & 2,73 & 2,81 & 2,74 & 2,72 \\
\hline Ternopil region & 2,53 & 2,58 & 2,66 & 2,96 & 2,92 & 3,06 & 3,06 \\
\hline Khmelnytskyi region & 3,18 & 3,06 & 3,27 & 3,69 & 3,82 & 3,9 & 3,88 \\
\hline Chernivtsi region & 2,04 & 2,04 & 2,05 & 2,33 & 2,45 & 2,52 & 2,44 \\
\hline Kyiv city & 6,2 & 6,23 & 6,77 & 7,65 & 7,44 & 7,69 & 7,57 \\
\hline Vinnytsia region & 3,66 & 3,52 & 3,58 & 4,08 & 4,17 & 4,1 & 4 \\
\hline Zhytomyr region & 2,66 & 2,64 & 2,74 & 3,09 & 3 & 3,15 & 3,13 \\
\hline Kyiv region & 3,45 & 3,53 & 3,73 & 4,27 & 4,41 & 4,57 & 4,8 \\
\hline Kirovohrad region & 2,75 & 2,63 & 2,64 & 2,92 & 2,82 & 2,82 & 2,78 \\
\hline Poltava region & 3,24 & 3,3 & 3,42 & 3,83 & 3,8 & 3,74 & 3,64 \\
\hline Sumy region & 2,51 & 2,55 & 2,54 & 2,8 & 2,76 & 2,72 & 2,64 \\
\hline Cherkasy region & 3,11 & 3,1 & 3,28 & 3,73 & 3,71 & 3,7 & 3,67 \\
\hline Chernihiv region & 1,93 & 1,95 & 1,92 & 2,12 & 2,16 & 2,23 & 2,29 \\
\hline Zaporizhzhia region & 3,82 & 3,83 & 3,79 & 4,22 & 4,13 & 4,13 & 4,17 \\
\hline Mykolaiv region & 2,67 & 2,68 & 2,58 & 2,85 & 2,78 & 2,84 & 2,89 \\
\hline Odesa region & 5,89 & 5,84 & 6 & 6,79 & 6,73 & 6,88 & 6,94 \\
\hline Kherson region & 2,33 & 2,37 & 2,39 & 2,63 & 2,57 & 2,73 & 2,67 \\
\hline
\end{tabular}

Thus, every object (oblasts of Ukraine and Kyiv city) is marked by the data point in $p$-dimensional space of indicators where $p=7$. Due to the fact that every object's coordinates are different in the scale proportionality, the further data standardization is unnecessary. The data mathematically processed, 5 clusters have been obtained the main features of which are listed in table 2. Another important stage of the research was carrying out the dispersion analysis of the obtained results in order to evaluate significance of differences between 5 clusters under analysis. The final results are given in table 3 . As it can be seen, every connection is significant (for every chosen indicator $p<0,05$ ) which permits to use the previous results of the mathematically processed data further on. All statistic calculations were done with the help of statistical packages StatSoft. Inc. (2014) STATISTICA version 12.0 and Excel spreadsheet. The value $p<0,05$ was considered statistically significant.

Table 2. Coordinates of cluster centers $x_{k}^{(n)}$

\begin{tabular}{|c|c|c|c|c|c|}
\hline Year & $\begin{array}{c}\vec{x}^{(1)} \\
\text { (cluster 1) }\end{array}$ & $\begin{array}{c}\vec{x}^{(2)} \\
\text { (cluster 2) }\end{array}$ & $\begin{array}{c}\vec{x}^{(3)} \\
\text { (cluster 3) }\end{array}$ & $\begin{array}{c}\vec{x}^{(4)} \\
\text { (cluster 4) }\end{array}$ & $\begin{array}{c}\vec{x}^{(5)} \\
\text { (cluster 5) }\end{array}$ \\
\hline 2012 & 5,281945 & 3,372968 & 8,354638 & 2,363610 & 6,187835 \\
\hline 2014 & 5,443351 & 3,341457 & 8,433229 & 2,367181 & 6,182191 \\
\hline 2015 & 4,597346 & 3,466008 & 7,641674 & 2,399980 & 6,359149 \\
\hline 2016 & 1,934441 & 3,916864 & 4,202232 & 2,675892 & 7,153897 \\
\hline 2017 & 2,877557 & 3,950524 & 4,375061 & 2,659293 & 6,910052 \\
\hline 2018 & 1,689948 & 3,963563 & 4,449546 & 2,718570 & 6,993260 \\
\hline 2019 & 2,080504 & 3,949442 & 4,927255 & 2,697866 & 6,883608 \\
\hline
\end{tabular}


Table 3. Dispersion analysis results to determine the significant deviation between derived clusters

\begin{tabular}{|c|c|c|c|c|}
\hline Year & Dispersion between clusters & Dispersion within clusters & Criterion $F$ & $\begin{array}{c}\text { Significance } \\
p\end{array}$ \\
\hline 2012 & 73,53915 & 3,850120 & 95,5024 & 0,000000 \\
\hline 2014 & 74,75191 & 3,647748 & 102,4631 & 0,000000 \\
\hline 2015 & 68,61015 & 3,896876 & 88,0322 & 0,000000 \\
\hline 2016 & 71,63065 & 4,828176 & 74,1798 & 0,000000 \\
\hline 2017 & 61,73709 & 3,357594 & 91,9365 & 0,000000 \\
\hline 2018 & 66,76771 & 3,208734 & 104,0406 & 0,000000 \\
\hline 2019 & 63,09622 & 4,022519 & 78,4287 & 0,000000 \\
\hline
\end{tabular}

The research results. According to the research results, and taking into account the dynamics change of the specific weight of SP number (\%) in Ukrainian regions during 2012-2019, all regions were divided into 5 clusters (figure 1). Figure 2 illustrates the centers of the clusters built by the mathematical results of the processed statistical data, and figure 4 - the full set of the specified clusters. So, after annexation of the Crimea Autonomous Republic Ukraine has currently 25 (100,0\%) administrative territorial units. One can see that according to figure 4 cluster 1 includes Luhansk region, cluster $2-8$ regions of Ukraine (32,0\% of the total of administrative territorial units of the country), cluster 3 - one region, namely Donetsk one, cluster $4-10$ regions (40,0\% correspondingly), and cluster $5-4$ regions and Kyiv city (20,0\% correspondingly). The graph results of Ukrainian region grouping are given in figure 3. It is necessary to take a detail analysis of the dynamics change character of the specific weight indicator (\%) of SP number in different Ukrainian regions separately for every cluster.

The most problematic regions which constituted cluster 1 and cluster 3 are Luhansk region and Donetsk region (figure 4). The characteristic feature of the indicator values under analysis in the described regions is its sharp fall in 2016. It can be logically explained by the fact that many pharmacies have been functioning on the temporally occupied and uncontrolled territories of Ukraine since 2014-2015. Herewith, in 2014-2015 those Ukrainian regions were actively developing as to increase pharmacy chains at the regional and national level. The division of the two regions into different clusters is conditioned by the fact that the dynamics of the index under analysis in Luhansk region is much worse than that in Donetsk one. Hence, these clusters can conventionally be called problematic ones. The population of these regions especially suffers from incapability of governmental institutions and business structures to provide accessible and efficient pharmaceutical care. A little improvement of the situation and increase of values were positive in Donetsk region in 2016 and in Luhansk one in 2018. In other words, even in conditions of extremely unstable political and humanitarian situation in the specified regions throughout 2014-2015, PM was able to actively react to negative changes of the environment.

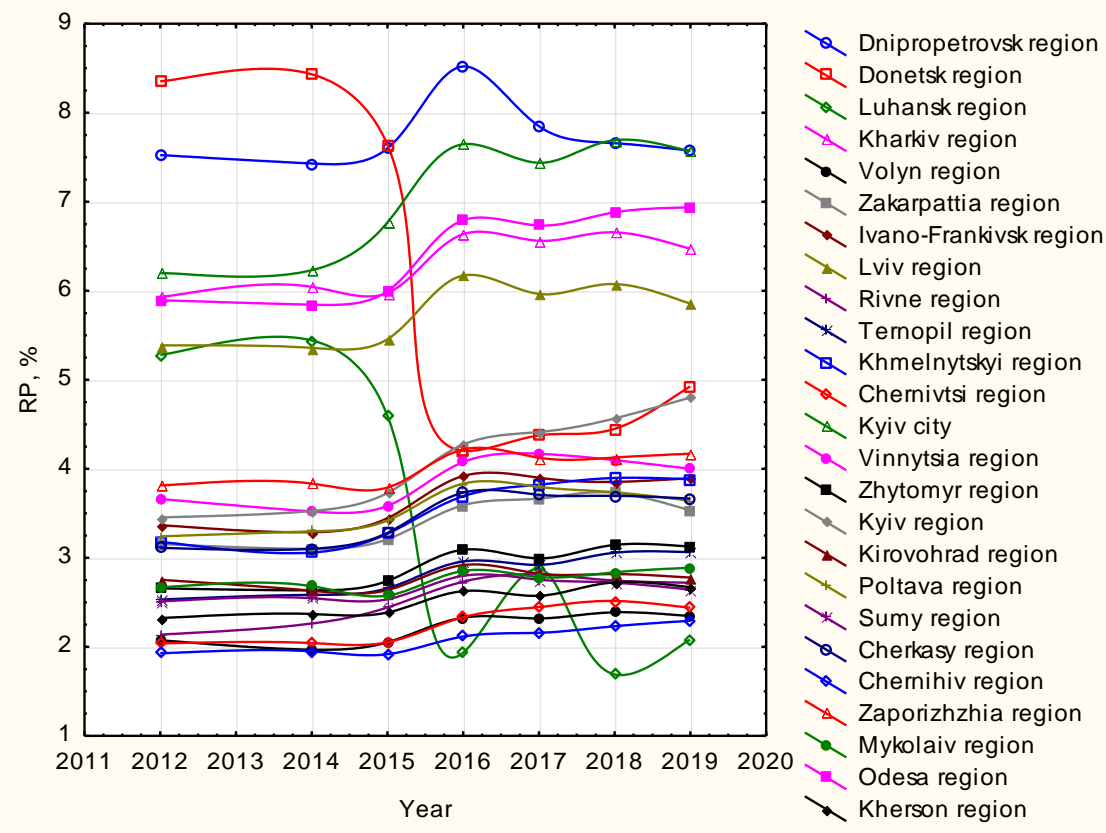

Fig.1. Dynamics change of the specific weight indicator of the SP number (\%) in Ukrainian regions (2012-2019) 


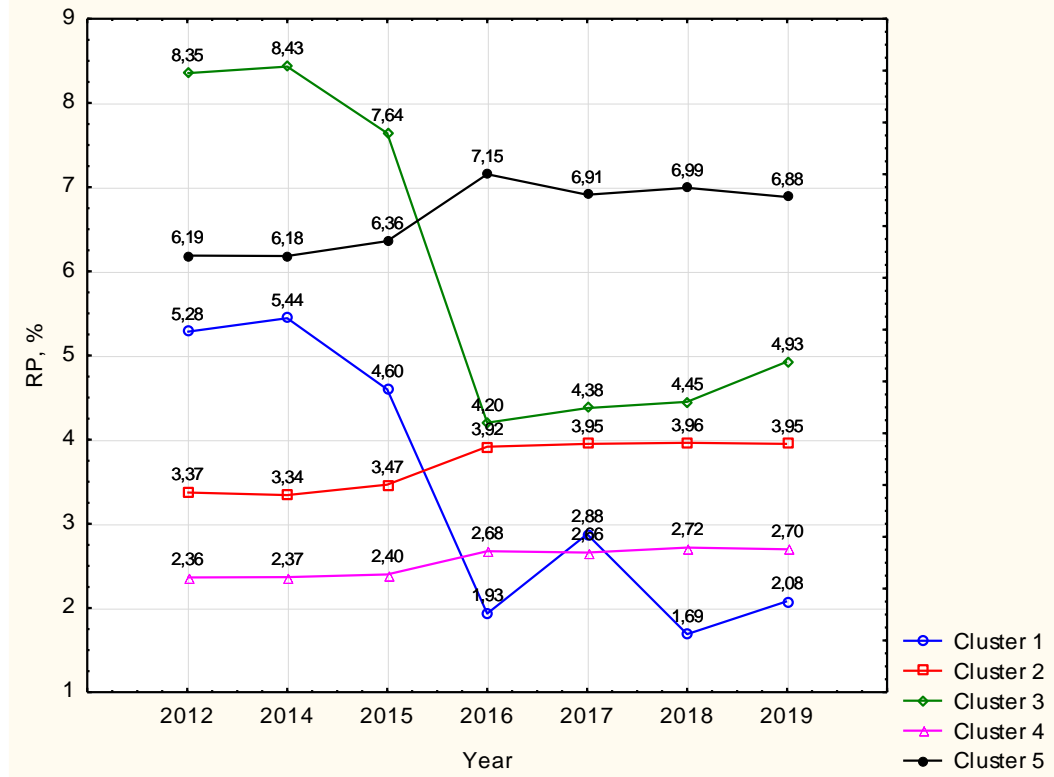

Fig. 2. Coordinates of cluster centers by the obtained research results (25 administrative territorial units of the country)

Table 4. Ukrainian regions by belonging to one of 5 clusters and distance to the center of the built cluster

\begin{tabular}{|l|c|c|l|c|c|}
\hline \multicolumn{1}{|c|}{ Region (oblast) } & Cluster & Distance & Region (oblast) & Cluster & Distance \\
\hline Luhansk region & 1 & 0,0 & Chernivtsi region & 4 & 0,278133 \\
\hline Zakarpattia region & 2 & 0,288796 & Zhytomyr region & 4 & 0,293067 \\
\hline Ivano-Frankivsk region & 2 & 0,054664 & Kirovohrad region & 4 & 0,363927 \\
\hline Khmelnytskyi region & 2 & 0,181565 & Sumy region & 4 & 0,233481 \\
\hline Vinnytsia region & 2 & 0,178679 & Chernihiv region & 4 & 0,119552 \\
\hline Kyiv region & 2 & 0,469126 & Mykolaiv region & 4 & 0,471938 \\
\hline Poltava region & 2 & 0,168061 & Kherson region & 4 & 0,215181 \\
\hline Cherkasy region & 2 & 0,240016 & Dnipropetrovsk region & 5 & 1,105736 \\
\hline Zaporizhzhia region & 2 & 0,325184 & Kharkiv region & 5 & 0,3584729 \\
\hline Donetsk region & 3 & 0,0 & Lviv region & 5 & 0,9165661 \\
\hline Rivne region & 4 & 0,344772 & Kyiv city & 5 & 0,4858556 \\
\hline Ternopil region & 4 & 0,114994 & Odesa region & 5 & 0,269529 \\
\hline Volyn region & 4 & 0,248352 & & & \\
\hline
\end{tabular}

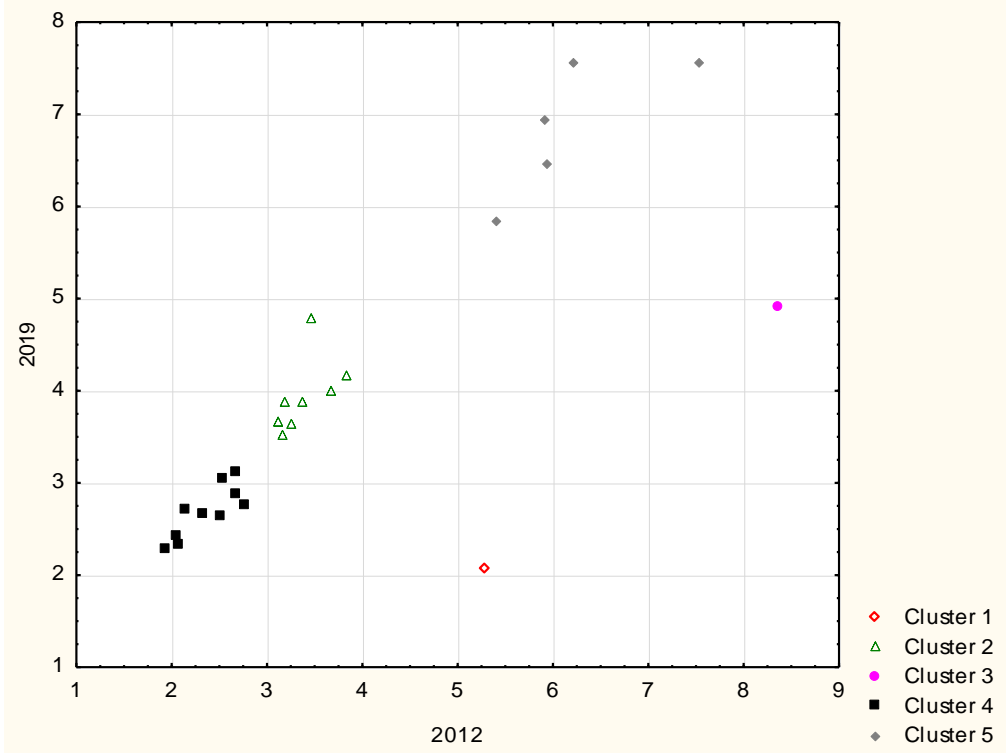

Fig. 3. Clusterization of Ukrainian regions projected on the 1st (2012) and 7th (2019) coordinate of time count down 
Luhansk region draws attention by the fact of unstable dynamics of the indicator under analysis. The governmental bodies should pay particular attention to the territories located closest to the temporally uncontrolled territories of Ukraine as to implement special mechanisms to stimulate pharmaceutical business development there. That said, it can be stated that cluster 1 and 3 were conventionally named «The most Problematic to Develop Cluster» and «The Problematic Development Cluster» correspondingly. Figures 5-7 show indicators data of the $2 \mathrm{~d}, 4^{\text {th }}$ and $5^{\text {the }}$ cluster.

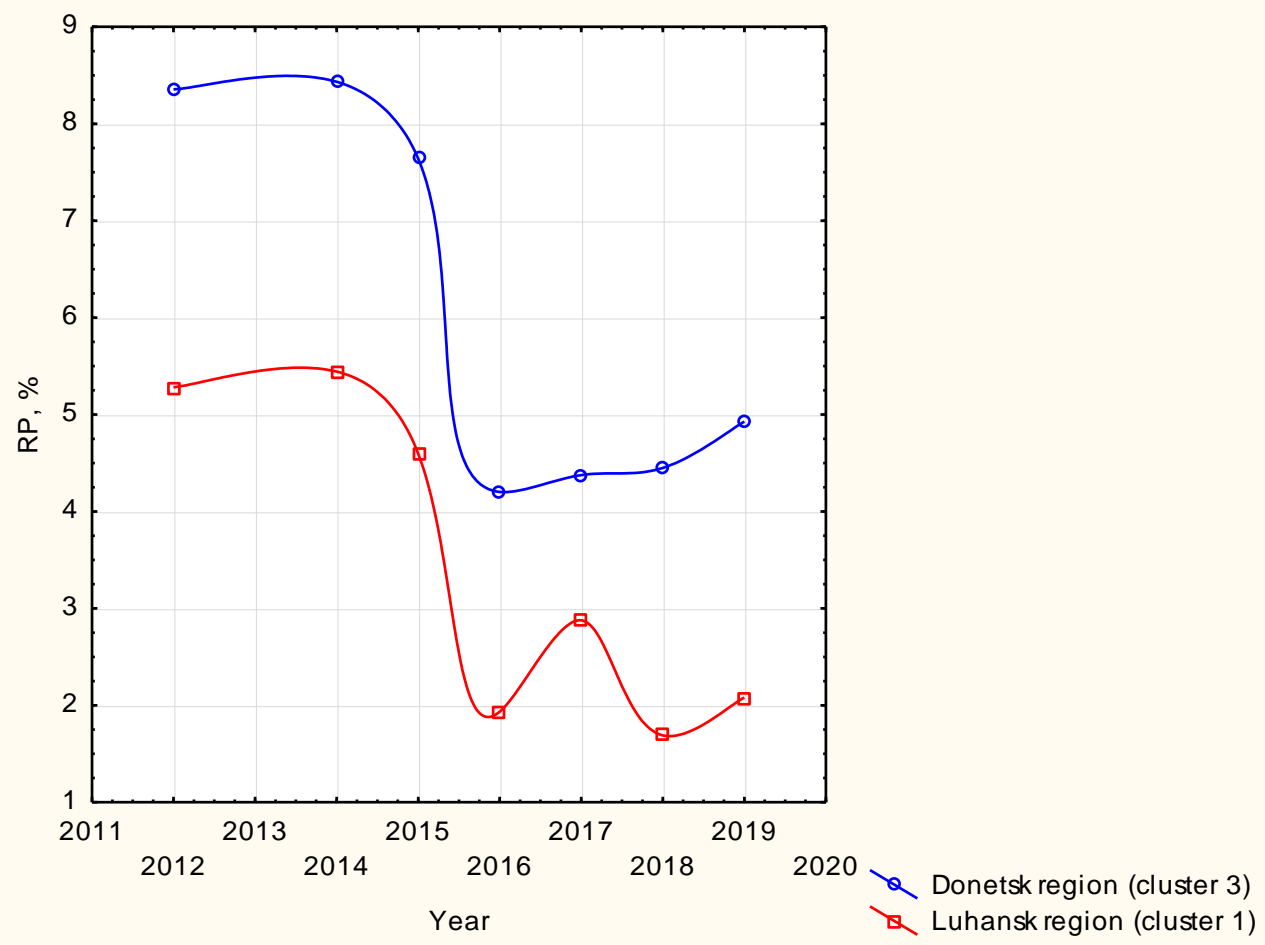

Fig. 4. Dynamics of the SP number change (\%) varying by the country's regions from the lst to the $3 d$ cluster

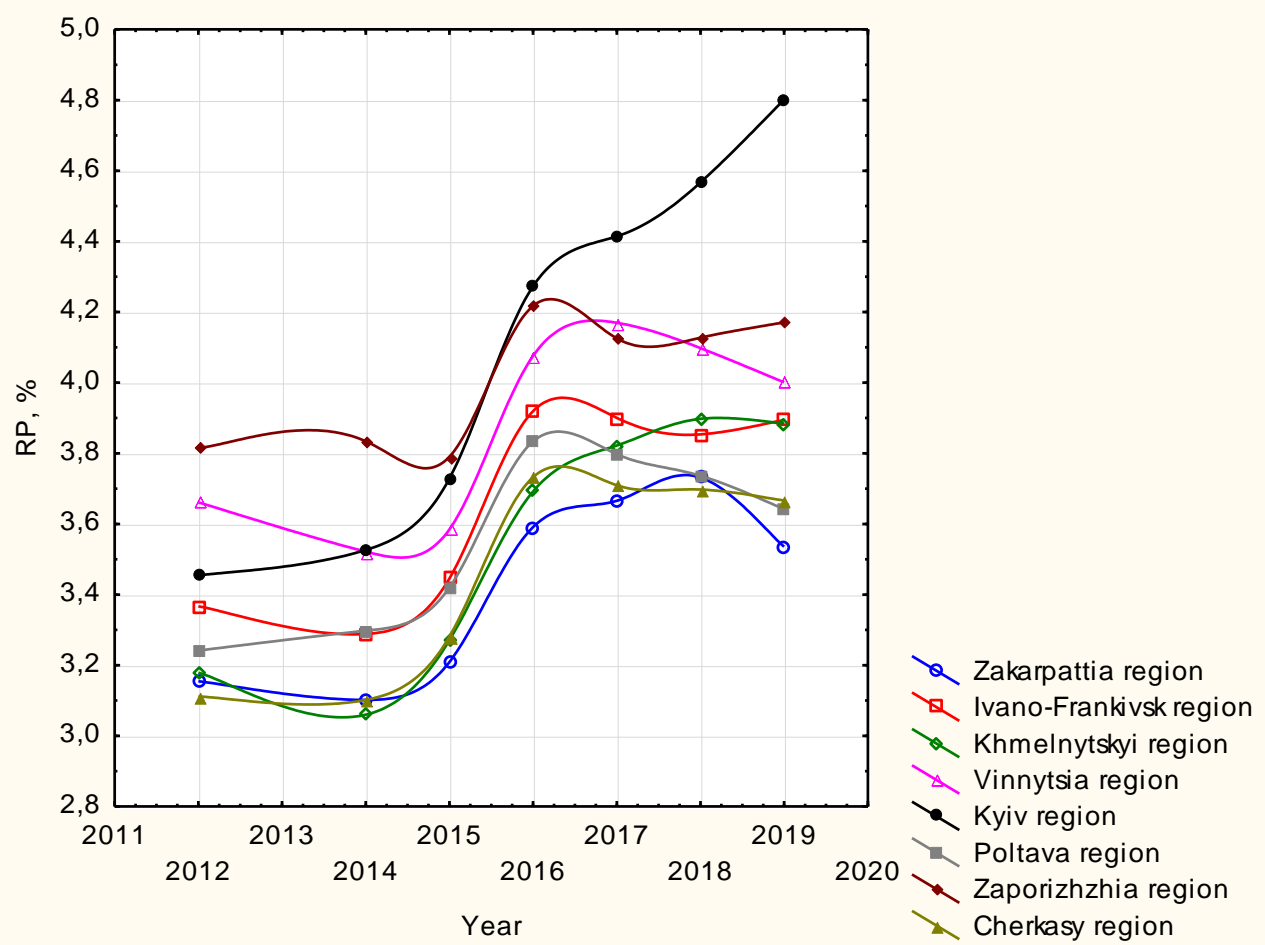

Fig. 5. Analysis of change dynamics of the SP number (\%) varying by the country's regions from the $2 d$ cluster 
The $2 \mathrm{~d}$ cluster included the regions characterized by the zigzagging dynamics of the analyzed indicators. Eight administrative territorial units showed peak values of growth of the analyzed index in 2016, the stabilized values of data in 2017 and gradual increase of growth in 2018-2019. It should be noted that in 2016 the described indicators exceeded the values of 2012 by almost two times. The cluster was conventionally named a «Zigzagging Increase Cluster». It is worth mentioning separately that Kyiv region had a rapid growth of the index under analysis throughout 2016-2019.

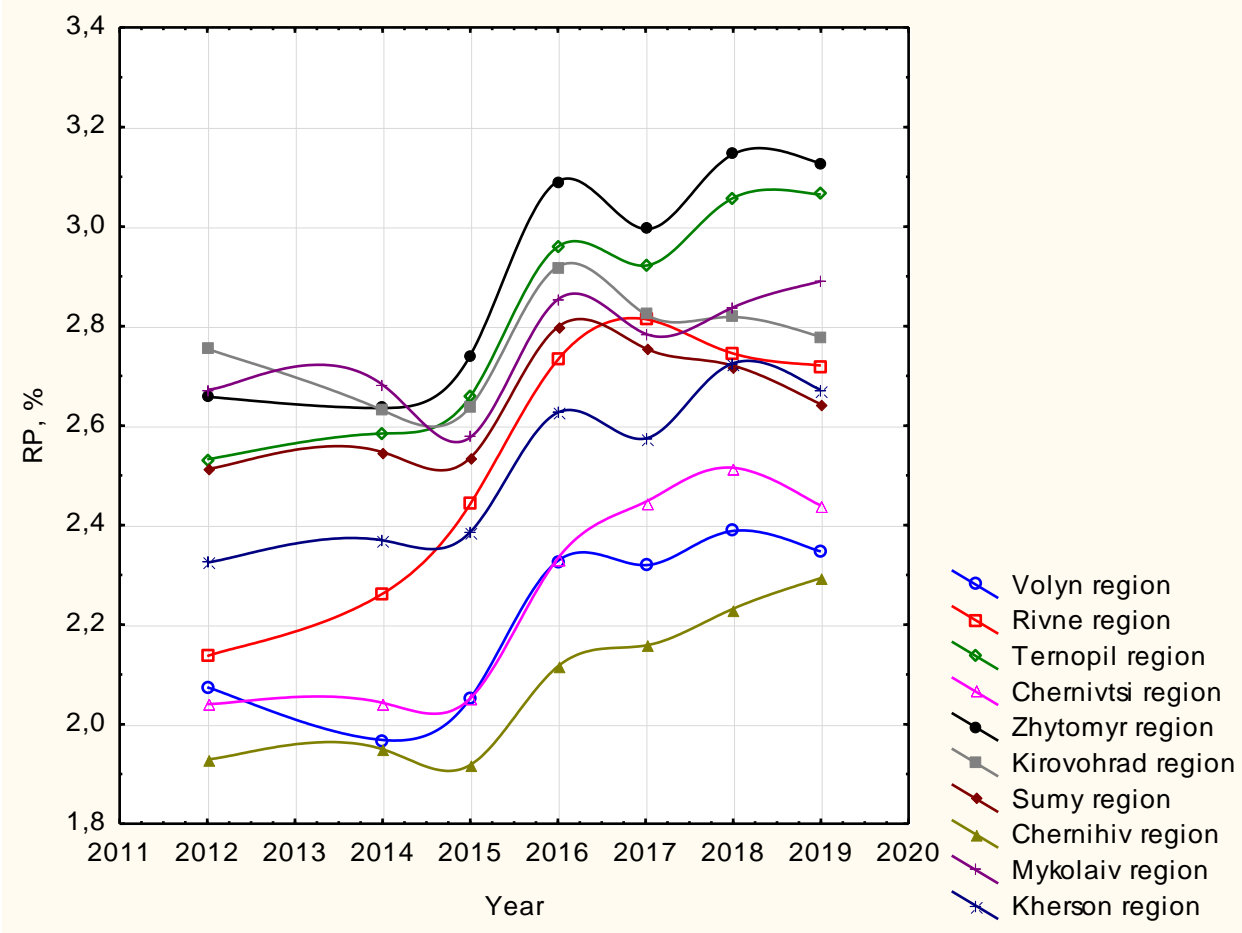

Fig. 6. Dynamics of the SP number (\%) varying by the country's regions from the $4^{\text {th }}$ cluster

As mentioned above, the $4^{\text {th }}$ cluster included 10 regions. Every region of the $4^{\text {th }}$ cluster was characterized by increased indices throughout 2016-2019 in comparison to the data of 2012. The regions of the $4^{\text {th }}$ cluster were conventionally divided into two subgroups according to the dynamic of indices change throughout 2018-2019. The first subgroup of the $4^{\text {th }}$ cluster was represented by the regions where the index to analyze was decreasing. Those were Zhytomyr region, Ternopil region, Kirovohrad region, Rivne region, Kherson region, Sumy region, Chernivtsi region, and Volyn one. The second subgroup included the regions where the index increase was observed, for example Mykolaiv and Chernihiv regions.

Most of the regions constituting the mentioned above cluster are agriculture-oriented economy regions located in the central or western part of the country. That cluster was conventionally named a «Positive-Perspective Development Cluster».

Cluster 5 included the regions which currently represent the country in industrial and scientifictechnological spheres. Moreover, human capacities are concentrated in these regions, and the population density is the highest. The 5-th cluster constitutes such administrative territorial units as Dnipropetrovsk region, Kharkiv region, Odesa region, Lviv region and Kyiv city. As we see in figure 7 throughout 20122014 a relatively stable situation was observed judging by the indicators under analysis in the graph. That is, PM responded to changes, which took place in the country and in the system of pharmaceutical provision throughout 2012-2015, relatively inertly. In 2016 in the administrative territorial units of cluster 5 one could observe a sharp increase of the mentioned indicators up to the maximally significant ones in Dnipropetrovsk region. However, in 2017 we can see the indicators' drop but the tendency was unstable (except Dnipropetrovsk region) and in the following 2018 the indicators under analysis grew again, although the rate of increase was much slower than in 2016. 


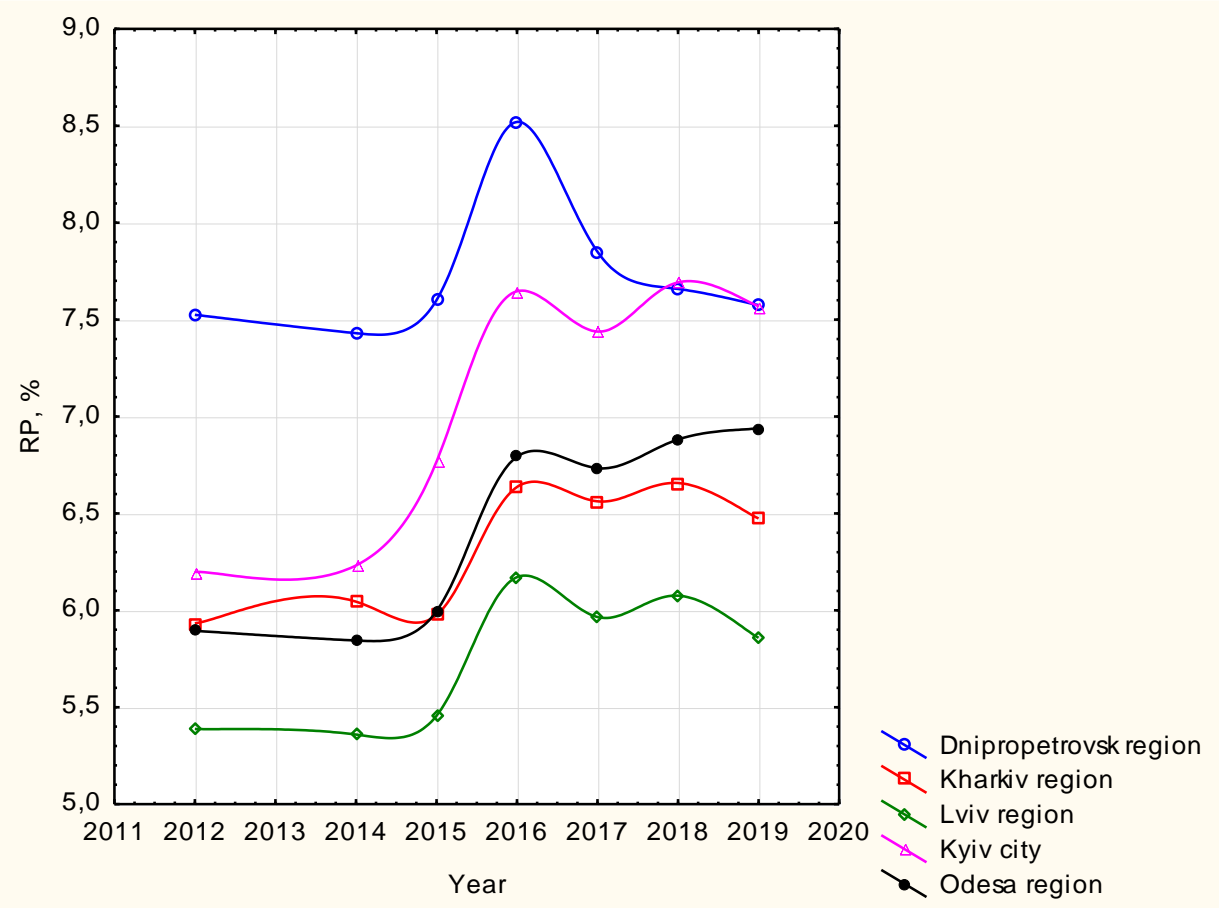

Fig. 7. Dynamics of the specific weight change of SP number (\%) varying by the country's regions from the $5^{\text {th }}$ cluster

According to dynamics change of indicators which were analyzed during 2018-2019, the regions of the $5^{\text {th }}$ cluster were divided into three conventional subgroups. So, the first subgroup included the regions characterized by the zigzagging character of dynamics of the analyzed indicators (increase in 2018 and gradual decrease in 2019), namely Lviv region, Kharkiv region and Kyiv city. The second subgroup was Odesa region which was characterized by a stable growth of the indicator under analysis. The third subgroup included Dnipropetrovsk region which lost the top position as a leader by the specific weight indicator (\%) of pharmacies to the total pharmaceutical establishments in Ukraine and during 2018-2019 had a negative dynamics of decrease matching the indicator of Kyiv city. Having studied the features of the indicators change which were researched during 2012-2019, the group of the $5^{\text {th }}$ cluster regions was given a conventional name «Positive-Problematic Development Cluster». In general, by all administrative territorial units which constituted cluster 2, 4 and 5 exactly 2016 was characterized by almost explosive growth of the specific weight indicator (\%) of SP number to the total of the country.

Conclusions.

1. According to the results of the cluster analysis of specific weight indicators (\%) of pharmacies of the total in Ukraine it has been established that all administrative territorial units of the country constitute 5 clusters. Every cluster is characterized by a different type of indicator development which has been analyzed in dynamics for several years.

2. It has been proved that cluster 1 includes Luhansk region, cluster $2-8$ regions of Ukraine (32,0\% of the total of administrative territorial units of the country), cluster 3 - one region, namely Donetsk one, cluster $4-10$ regions (40,0\% correspondingly), and cluster $5-4$ regions and Kyiv city (20,0\% correspondingly).

3. The clusters have been given conventional names by the character of indicators change to analyze. They are as follows: cluster 1 and 3 are «The most Problematic to Develop Cluster» and «The Problematic Development Cluster» correspondingly. Cluster 2 (the zigzagging dynamics of the analyzed indicators) - «Zigzagging Increase Cluster». Cluster 4 - «Positive-Perspective Development Cluster». Cluster 5 - «Positive-Problematic Development Cluster» which characterized by tremendous increase of indicator value in 2016 and gradual decrease in 2019.

4. It has been proved that the common feature of indicators dynamics for the regions from cluster 2, 4, and 5 is a peak like character of data increase which was analyzed in 2016 . The fact is the consequence of the relative stabilization of political, financial, and socioeconomic situation in the 
country after the crisis in 2014-2015. Thus, in 2016 every region of the $2 d, 4^{\text {th }}$ and $5^{\text {th }}$ clusters was characterized by the higher indicator value than in 2012 .

5. Determining the main factors which affect dynamics of the indicators under analysis is a viable further development of the research. The reported results can be applied to develop efficient ways of implementing the state innovations to regulate the retail of the national PM at the regional level.

\section{REFERENCES}

1. Bush PW, Daniels R. Health care systems and transitions of care: implication on interdisciplinary pharmacy services. N C Med J. 2017;78(3):177-80. doi: 10.18043/ncm.78.3.177.

2. Damian Świeczkowski, Piotr Merks, Natalia Cwalina, Miłosz J. Jaguszewski. Development of Pharmacy Practice in European Countries - The Polish Perspective. Pharmacy (Basel). 2017;5(43). Available from: https://www.mdpi.com/2226-4787/5/3/43/htm. doi: 10.3390/pharmacy5030043.

3. Eades CE, Ferguson JS, O'Carroll RE. Public health in community pharmacy: a systematic review of pharmacist and consumer views. BMC Public Health. 2011;11:582. Available from: https://www.ncbi.nlm.nih.gov/pmc/articles/PMC3146877/

4. Pogorzelczyk K, Synoweć J, Robakowska M, Ślęzak D, Holajn P, Robakowski P, Żuratyński P, Nadolny K. Pharmaceutical markets regulation overview of the selected European Union countries. Wiad Lek. 2018;71(7):1404-8.

5. Rubio-Valera M, Chen TF, O'Reilly CL. New roles for pharmacists in community mental health care: a narrative review. Int. J. Environ. Res. Public Health. 2014;11(10):10967-90. doi: 10.3390/ijerph111010967.

6. Sadek MM, Elnour AA, Al Kalbani NM, Bhagavathula AS, Baraka MA, Aziz AM, et al. Community pharmacy and the extended community pharmacist practice roles: The UAE experiences. Saudi Pharm. J. 2016;24(5):563-70. doi: 10.1016/j.jsps.2015.03.023.

7. Volk N.V., Svitlychnyi O.P. Administrativno-pravove reguliuvannia farmatsevtychnoi diialnosti v Ukraini: shliahy vdoskonalennia: monograf. K.: NUBiP Ukrainy, 2018. $185 \mathrm{~s}$.

8. Volodarskyi E.T., Kosheva L.O. Statystychna obrobka danykh: navch. posibnyk. K.: NAU, 2008. 308 s.

9. Pistunov I.M., Antoniuk O.P., Turchaninova I.Y. Klasternyi analiz v ekonomitsi: navch. posibnyk. Dnipropetrovsk: Natsionalnyi girnychyi universytet, 2008. $84 \mathrm{~s}$.

10. Nemchenko A.S., Nazarkina V.M., Panfilova G.L. ta in. Organizatsiia ta ekonomika frmatsii. Organizatsiia farmatsevtychnoho zabezpechennia naselennia: nats. pidruchnyk. Za red. A.S. Nemchenko. Kharkiv, NFaU: Zoloti storinky, 2015. Ch. 1. $360 \mathrm{~s}$.

11. Proekt Zakonu pro vnesennia zmin do Zakonu Ukrainy «Pro likarski zasoby» schodo zabespechennia ekonomichnoi konkurentsii ta prav patsiientiv pry zdiisnenni rozdribnoi torhivli likarskymy zasobamy. 2018. Rezhym dostupu: http://w1.c1.rada.gov.ua/pls/zweb2/webproc4_1?pf3511=64412 